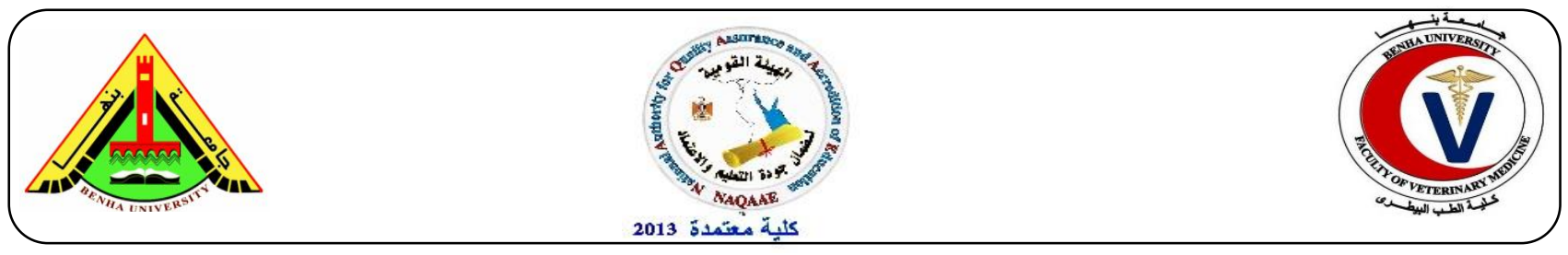

\title{
Antiobesity activity and hypolipidemic effect of Proanthocyanidins in rats fed a high fat diet
}

\author{
Samy A. Hussein; Yakout A. El-Senosi, Ghada, H. EL-Sharkawy
}

Department of Biochemistry, Faculty of Vet. Med., Benha University, Egypt.

*Corresponding author: Samy Ali Hussein; email: samyaziza@yahoo.com-samy.aziza@fvtm.bu.edu.eg

\section{A B S T R A C T}

Proanthocyanidins, also known as condensed tannins, can prevent obesity induced oxidative stress damage in the liver. This study aimed to evaluate the protective effect of Proanthocyanidins on obesity induced oxidative stress and biochemical abnormalities in male rats. Forty-eight male albino rats were divided into three equal groups. Group I (control normal): rats received normal diet. Group II (Obesity): rats received high fat diet (HFD). Group III (Obesity+ Proanthocyanidins): rats received Proanthocyanidins $(50 \mathrm{mg} / \mathrm{kg}$. b.wt.) orally for two months after induction of obesity. The obtained results showed significant increase in serum insulin, lipids profile (total cholesterol and triacylglycerols) concentrations, liver L-MDA in addition to up regulation of leptin and Nuclear factor kappa B $(\mathrm{NF}-\kappa \mathrm{B})$ gene expression level in liver tissues of obese rats. However, liver catalase activity and GSH concentration were markedly decreased. These results suggested that, Proanthocyanidins treatment exerts a protective effect on obesity by reduction of oxidative stress, inflammation and hyperlipidemia in rats through free radical scavenging and anti-inflammatory activities as well as regenerating endogenous antioxidant defense system mechanisms.

Keywords: Obesity, Proanthocyanidins, oxidative stress, insulin, leptin

\section{INTRODUCTION}

Obesity is the excessive fat accumulation in the body, chronic and nutritional disorder and insulin resistance metabolic syndrome (You et al., 2014) which indirectly reduced life quality and cause mortality and morbidity (Cherniack, 2008). Obesity has been officially recognized as an independent disease entity by the American Medical Association. The World Health Organization (WHO) has classified obesity as one of the leading risk factors for global deaths due to its tight association with multiple chronic diseases, such as cardiovascular disease, type II diabetes, and certain forms of cancers (Haslam and James, 2005). There are many different options for obesity treatments, including dietary control, exercise, life-style changes, prescription weight-loss medications, and weight-loss surgeries (Chandrasekaran et al, 2012).

Proanthocyanidins are a class of flavonoid compounds that are present in many food and drinks such as fruits, vegetables, and red wine, and thus they are very abundant in the human diet, have been defined as healthy 
bioactive compounds (Blade et al., 2016). Several studies have reported many beneficial effects of (GSPE) on various obesity associated diseases, such as insulin resistance, (Montagut et al., 2010) dyslipidaemia, (Quesada et al., 2009) hypertension, (Pons et al., 2014) inflammation (Martinez-Micaelo et al., 2012) and leptin resistance (Ibars et al., 2017).

Proanthocyanidins (PA) is structurally diverse, including with regard to the number of monomer units involved. The PA that consist exclusively of epicatechin and catechin units are called procyanidins and these are the most abundant type of PA in plants. Grape seed extract (GSE) is a good source of PA containing abundant oligomers and polymers of monomeric units of (-)-epicatechin or (+)catechins, including the gallated forms the ability of a compound to act as an antioxidant depends highly on its chemical structure (Manach et al., 1996). There are studies with different animal models and with PA rich extracts from different sources, indicating that $\mathrm{PA}$ reduces fat and body weight. In fact, PA appears to reduce the body weight gain rather than to reduce the body weight (Pajuelo et al., 2012). Furthermore, proanthocyanidins is a potent scavenger of peroxyl and hydroxyl radicals that is generated in the reperfusion myocardium after ischemia (Pataki et al., 2002). In addition to the ability to scavenge ROS, GSP has the ability to stimulate NO production in a dose dependent manner, which is a relatively stable free radical and acts as a signaling molecule in diverse physiological and pathological pathways.

This study was to investigate the possible beneficial effect of Proanthocyanidins against deleterious effect of obesity in adult male rats through investigation of insulin, lipid profile, inflammatory markers, biomarkers of oxidative stress.

\section{MATERIALS AND METHODS}

\section{Experimental animals:}

Forty-eighth white male albino rats of 12-16 weeks old age and average body weight 160$200 \mathrm{~g}$ were used in this study. Rats were housed in separated metal cages and kept at constant environmental and nutritional conditions throughout the period of experiment. Rats were fed on constant ration and fresh, clean drinking water was supplied ad-libitum. All rats were acclimatized for minimum period of 15 days prior to the beginning of study.

Ration and additives:

There are two type of ration were prepared freshly and daily throughout the course of experiment: a standard diet with protein $20 \%$; fat 5\%;carbohydrates 5\%; fiber 5\% and a high-fat diet with $20 \%$ of energy derived from protein; $15 \%$ from corn oil; $50 \%$ from sucrose; 5\% from fiber (Surapaneni and Jainu, 2014).

\section{Induction of obesity:}

The experimental induction of obesity in male rats was induced by feeding the rats on the prepared high fat diet (HFD) for eight weeks before the beginning of the experiment. The diet was prepared, and necessary vitamins and minerals were added. For fatty diet the chow, in powder form, was mixed fat until become homogenous in a dough-like consistency. This dough was shaped with

a paste injector. The obtained chow blocks were dried and used for rats feeding for two months. After two months of obesity induction treatment with Proanthocyanidins were given and continued for additional two months.

\section{Chemicals and antioxidant:}

The antioxidant and chemicals used in the present study were:

a.Proanthocyanidins was provided by El- 
Debeky Co. For Trading Chemicals, Medicines And Medical Appliances, Egypt.

b- Dimethyl sulfoxide (DMSO) (100\%): Proanthocyanidins was dissolved in DMSO and further diluted with normal saline. The final concentrations of DMSO in solution were $<1 \%$. The freshly prepared solution of Proanthocyanidins was administered orally and daily at a dose of $50 \mathrm{mg} / \mathrm{kg}$. body weight for group III for two months (Gil Cardoso et al., 2017).

c- Other chemicals used in this study were of the highest purified grades available purchased from El Gomhouria Company for Trading Chemicals and Medical Appliances, Egypt.

Experimental design:

After acclimatization to the laboratory conditions, the animals were randomly divided into three groups (10 rats each) placed in individual cages and classified as follow:

Group I (normal control group): Rats received normal diet, served as control non- treated for all experimental groups.

Group II (Obesity group): Rats received high fat diet (HFD) ad-libitum, served as obesity induced rats group.

Group III (Obesity+proanthocyanidins treated group) rats received proanthocyanidins orally at a dose of (50 mg/kg.b.wt./day) for 2 months after induction of obesity.

\section{Sampling:}

Blood samples and liver tissue specimen were collected from all animal groups (control and experimental groups) once after the end of 4 months.

\section{Blood samples:}

Blood samples were collected by ocular vein puncture from all animal groups after overnight fasting in dry, clean tubes and allowed to clot for 30 minutes and serum was separated by centrifugation at 3000 r.p.m for 15 minute. The serum was taken by automatic pippte and received in dry sterile tubes, then kept in deep freeze at $-20{ }^{\circ} \mathrm{C}$ until use for subsequent biochemical analysis. All sera were analyzed for determination of the following parameters: Insulin, Total cholesterol and Triacylglycerols.

Tissue samples:

Liver tissue for biochemical analysis:

About $0.5 \mathrm{~g}$ of liver tissue specimen was taken from each group of rats after had been euthanized. The specimens were immediately removed and washed several times with saline and blotted between two damp filter papers, weighed and stored at $-20^{\circ} \mathrm{C}$ for subsequent biochemical analysis.

Preparation of liver tissue homogenate:

Briefly, liver tissues were cut, weighed and minced into small pieces, homogenized with a glass homogenizer in 9 volume of icecold $0.05 \mathrm{mM}$ potassium phosphate buffer (pH 7.4) to make $10 \%$ homogenates. The homogenates were centrifuged at 6000 r.p.m for 15 minutes at $4{ }^{\circ} \mathrm{C}$ then the resultant supernatant was used for the determination of the following parameters: L-MDA and Catalase.

About $0.2 \mathrm{~g}$ of liver tissues were minced into small pieces homogenized with a glass homogenizer in $0.4 \mathrm{ml}$ of $25 \%$ metaphosphoric acid (MPA) (ref. No.: 253433-4, Sigma-Aldrich, Germany), then 1.4 $\mathrm{mL}$ of distilled water was added, mixed and incubated for 1 hour and centrifuged for 10 min at 3,000 r.p.m then the clear supernatant was removed and used for determination of GSH concentration.

Liver tissue for molecular analysis:

About $0.5 \mathrm{~g}$ of liver tissue put in eppendorf tubes and were immediately kept in liquid nitrogen and stored at $-80^{\circ} \mathrm{C}$ till RNA extraction for determination of Leptin and $\mathrm{NF}-\kappa \mathrm{B}$ gene expression level. 


\section{Biochemical analysis}

Serum Insulin was determined according to the method described by Wilson and miles, (1977). Total cholesterol and Triacylglycerols were determined according to the method described by NCEP expert panel, (1988) and Stein, (1987), respectively. Liver tissue L-MDA, CAT and GSH were determined according to the method described by Mesbah et al., (2004), Luck, (1974) and Moron et al., (1979).

\section{Molecular analysis}

Total RNA was isolated from liver tissue of rats using RNeasy Mini Kit (Thermo Qiagen, \#74104) according to the manufacturer's protocol. Following determination of RNA concentration and purity by Quawell nanodrop Q5000 (USA), $5 \mathrm{mg}$ of total RNA from each sample was reverse transcribed using Quantiscript reverse transcriptase. The produced cDNA was used as a template to determine the relative expression of Leptin and NF- $\kappa$ B genes using Step One Plus real time PCR system (Applied Biosystem, USA) and gene specific primers. The reference gene, $\beta$ actin, was used to calculate fold change in target genes expression. The thermal cycling conditions, melting curves temperatures, and calculation of relative expression was done. For the treated groups, assessment of $2^{-\Delta \Delta \mathrm{Ct}}$ determined the fold change in gene expression relative to the control (Livak and Schmittgen, 2001).

Forward and reverse primers sequence for real time PCR.

\begin{tabular}{|c|c|c|}
\hline Gene & $\begin{array}{l}\text { Forward primer } \\
\left({ }^{\prime} 5---{ }^{/} 3\right)\end{array}$ & $\begin{array}{l}\text { Reverse primer } \\
(\text { '5 ----- } 3)\end{array}$ \\
\hline Leptin & GACATTTCACACACGCAGTC & GAGGAGGTCTCGCAGGTT \\
\hline $\mathrm{NF}-\kappa \mathrm{B}$ & CCTAGCTTTCTCTGAACTGCAAA & GGGTCAGAGGCCAATAGAGA \\
\hline$\beta$-actin & ACCCACACTGTGCCCATCTA & CGTCACACTTCATGATG \\
\hline
\end{tabular}

\section{Statistical analysis:}

The results were expressed as mean \pm SE using SPSS (13.0 software, 2009) program. The data were analyzed using oneway ANOVA to determine the statistical significance of differences among groups. Duncan's test was used for making a multiple comparisons among the groups for testing the inter-grouping homogeneity. Values were considered statistically significant when $\mathrm{p}<0.05$.

\section{RESULTS:}

The data presented in table (1) showed a significant increase in serum insulin, total cholesterol and Triacylglycerol concentrations in obesity-induced rats when compared to normal control group. However,
Proanthocyanidins treatment to obese male rats caused a significant decrease in elevated serum insulin, total cholesterol and Triacylglycerol concentrations when compared with obesity induced group.

The obtained results presented in table (2) revealed that, obese rats showed significant increase in liver tissue L-MDA and significant decrease in Enzymatic antioxidant catalase and Non-enzymatic antioxidant reduced glutathione (GSH) when compared with normal control group. On the other hand, Proanthocyanidins treatment to obese male rats caused a significant decrease in liver tissue L-MDA with marked increase in catalase activity and GSH concentration when compared with in obesity-induced rats. 
The $\mathrm{qPCR}$ results presented in table (3) showed a significant up-regulation in relative expression of Leptin and $\mathrm{NF}-\kappa \mathrm{B}$ gene level in liver tissue of obesity induced rats when compared to normal control group.
However, Proanthocyanidins treatment to obese rats caused a significant down-

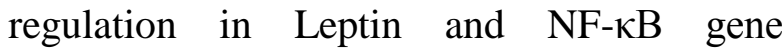
expression level when compared with obesity-induced rats.

Table (1): Effect of Proanthocyanidin administration on serum insulin, total cholesterol and triacylglycerols concentrations in obesity induced in male rats.

\begin{tabular}{|c|c|c|c|}
\hline Parameters & $\begin{array}{l}\text { Insulin } \\
\text { (ng/ml) }\end{array}$ & $\begin{array}{l}\text { Total Cholesterol } \\
(\mathrm{mg} / \mathrm{dl})\end{array}$ & $\begin{array}{l}\text { Triacylglycerols } \\
(\mathrm{mg} / \mathrm{dl})\end{array}$ \\
\hline Exp. groups & & & \\
\hline $\begin{array}{l}\text { Group I: } \\
\text { Normal control }\end{array}$ & $4.68 \pm 0.21^{\mathrm{c}}$ & $80.21 \pm 2.53^{c}$ & $57.15 \pm 2.83^{c}$ \\
\hline $\begin{array}{l}\text { Group } \Pi: \\
\text { (Obese) }\end{array}$ & $9.82 \pm 0.37^{\mathrm{a}}$ & $155.50 \pm 3.85^{\mathrm{a}}$ & $113.00 \pm 4.63^{\mathrm{a}}$ \\
\hline $\begin{array}{l}\text { Group III: } \\
\text { Obese + Proanthocyanidin }\end{array}$ & $7.45 \pm 0.31^{\mathrm{b}}$ & $99.30 \pm 2.45^{\mathrm{b}}$ & $83.00 \pm 3.04^{\mathrm{b}}$ \\
\hline
\end{tabular}

Data are presented as (Mean \pm S.E). $\quad$ S.E $=$ Standard error.

Mean values with different superscript letters in the same column are significantly different at $(\mathrm{P} \leq 0.05)$.

Table (2): Effect of Proanthocyanidin administration on liver tissue L-MDA, Catalase and GSH in obesity induced in male rats.

\begin{tabular}{|c|c|c|c|}
\hline Parameters & $\begin{array}{l}\text { L-MDA } \\
\text { (mmol/g tissue) }\end{array}$ & $\begin{array}{l}\text { Catalase } \\
\text { (ng/g.tissue) }\end{array}$ & $\begin{array}{l}\text { GSH } \\
\text { (ng/g.tissue) }\end{array}$ \\
\hline Exp. groups & & & \\
\hline $\begin{array}{l}\text { Group I: } \\
\text { Normal control }\end{array}$ & $11.14 \pm 0.52^{\mathrm{d}}$ & $6.72 \pm 0.38^{\mathrm{a}}$ & $113.07 \pm 4.15^{\mathrm{a}}$ \\
\hline $\begin{array}{l}\text { Group } \Pi: \\
\text { (Obese) }\end{array}$ & $25.60 \pm 1.01^{\mathrm{a}}$ & $2.10 \pm 0.15^{\mathrm{c}}$ & $47.23 \pm 1.82^{\mathrm{d}}$ \\
\hline $\begin{array}{l}\text { Group III: } \\
\text { Obese + Proanthocyanidin }\end{array}$ & $19.90 \pm 0.34^{\mathrm{b}}$ & $4.47 \pm 0.42^{\mathrm{b}}$ & $96.21 \pm 2.42^{b}$ \\
\hline
\end{tabular}

Data are presented as (Mean \pm S.E). $\quad$ S.E = Standard error.

Mean values with different superscript letters in the same column are significantly different at $(\mathrm{P} \leq 0.05)$. 
Table (3): Effect of Proanthocyanidin administration on relative expression of Leptin and NF-k $\beta$ gene in liver of obesity induced in male rats.

\begin{tabular}{|c|c|c|c|c|}
\hline \multirow{3}{*}{$\begin{array}{l}\text { Parameters } \\
\text { Exp. groups }\end{array}$} & \multicolumn{2}{|l|}{ Leptin } & \multicolumn{2}{|c|}{$\mathrm{NF}-\mathrm{k} \beta$} \\
\hline & \multicolumn{2}{|c|}{ Fold change } & \multicolumn{2}{|c|}{ Fold change } \\
\hline & mean & SEM & mean & SEM \\
\hline Group I: & $1.00^{\mathrm{d}}$ & 0.06 & $1.00^{\mathrm{d}}$ & 0.05 \\
\hline Normal control & & & & \\
\hline $\begin{array}{l}\text { Group } \Pi: \\
\text { (Obese) }\end{array}$ & $10.20^{\mathrm{a}}$ & 0.34 & $5.70^{\mathrm{a}}$ & 0.27 \\
\hline $\begin{array}{l}\text { Group III: } \\
\text { Obese+Moringa Oleifera }\end{array}$ & $4.23^{c}$ & 0.19 & $3.71^{\mathrm{b}}$ & 0.21 \\
\hline
\end{tabular}

Means within the same column carrying different superscript letters are significantly different $(\mathrm{P} \leq 0.05)$.

\section{DISCUSSION}

Cardiovascular disease (CVD), also known as heart and blood vessel disease, is the leading cause of death (Cook and Cantor, 2006).In most cases, these clinical conditions result from atherosclerosis, which was once identified as a lipid-storage disease. Obesity results from an imbalance of energy homeostasis, over an extended period of time, caused by the consumption of more calories than the body is able to burn. The cause of this imbalance is complex and is influenced by the convergence of various environmental, behavioral and genetic factors (Bray, 2004).

The obtained results revealed that, obesity-induced rats showed significant increase in serum insulin, total cholesterol and triacylglycerols concentrations when compared to normal control group. These results were nearly similar to (Woods et al., 2004) who recorded that, hyperinsulinemia and insulin resistance are induced by high-fat feeding. Also, Cyrus et al., (2003) showed that, mice fed HFD had a significant increase in both cholesterol and triglycerides, the higher concentrations of such lipid profile in the high fat fed rat lead to the development of abnormal lipid metabolism and atherosclerosis (Taboada et al., 2006). Insulin resistance in obesity is also characterized by chronic low-grade inflammation and reduced plasma levels of adiponectin, an adipokine that improves insulin sensitivity. Along with increased plasma levels of free fatty acids, hyperglycemia, and reactive oxygen species, these factors can change gene expression and cell signaling in vascular endothelium which also alters the release of endothelial vasoactive factors (Rask-Madsen and King, 2007). Loss of insulin action causes a shift in balance from oxidation to esterification of free fatty acids (FFAs), resulting in elevated very low-density lipoprotein (VLDL) secretion. Also, insulin resistance can be considered as additional factor which contributes to increased cardiovascular disease in obesity. The action of insulin is initiated by binding to its receptors and activation of intrinsic protein tyrosine kinase activity of the receptors, resulting in initiation of intracellular signaling cascade that eventually related to glucose and lipid metabolism (Westerbacka et al., 2002). It is well established that increased availability and utilization of free fatty acids (FFAs) play a critical role in the development of insulin resistance. Excess adipose tissue has been shown to release an increased amount of FFAs which directly affect insulin signaling, diminish glucose uptake in muscles, drive 
exaggerated triglyceride synthesis and induce gluconeogenesis in the liver leading to elevated levels of glucose and lipids (Mlinar et al., 2007). In general, the development and progression of atherosclerosis is considered to be a form of chronic inflammation (Ross et al, 1999). Endothelial dysfunction is the key process promoting inflammatory reactions (Wang et al., 2000).

Treatment with Proanthocyanidins to obese male rats caused a significant decrease in serum insulin, total cholesterol and triacylglycerol concentrations. These results were nearly similar to those recorded by Dorenkott et al., (2014) who found that, in mice fed a HFD, supplements consisting of proanthocyanidins prevented weight gain, impairment of glucose tolerance and insulin resistance. Also, Pallares et al., (2013) found that, chronic corrective treatment using proanthocyanidins (PA) ameliorates insulin in rats fed a cafeteria diet (CD). The effects of this extract might be partially explained by its insulin-like effect on insulin-sensitive cell lines, as well as through its effects on pancreatic $\beta$-cell function and by preventing the effects of the $\mathrm{CD}$ on insulin secretion and production and lipid accumulation in the pancreas. The antihyperglycaemic effect of Grape seed proanthocyanidins extract (GSPE) may be partially due to the insulinomimetic activity of the procyanidins using insulinsensitive cell lines (Pallares et al., 2013). PA act as a hypolipidemic agent (Arola et al., 2010), and improve inflammation (Terra et al., 2011) and insulin resistance. Pons et al., (2017) reported that, the daily administration of GSPE (at doses of $25 \mathrm{mg} / \mathrm{kg}$ per day, 100 $\mathrm{mg} / \mathrm{kg}$ per day, and $200 \mathrm{mg} / \mathrm{kg}$ per day) for 12 weeks together with a diet high in carbohydrates and fat in rats can mitigate the increase in blood pressure and plasma lipids levels in response to the obesogenic diet. The proanthocyanidin hypotriglyceridemic protective effect is in concordance with the preventive decrease in adipocyte hypertrophy in retroperitoneal white adipose tissue (rWAT), since visceral adipocyte hypertrophy has been associated with dyslipidemia (Veilleux et al., 2011).

The levels of the TG-rich lipoproteins, chylomicrons(CM) and very low-density lipoproteins (VLDL) depend on the secretion of these lipoprotein complexes by the intestine and the liver and on their catabolism by the lipoprotein lipase LPL) in extra-hepatic tissues. Interestingly, PA represses the secretion of VLDL-TG and CM-TG. Without affecting LPL activity or expression in WAT and muscle (Quesada et al., 2012). Therefore, it is possible that the PA reduce plasma TG by repressing lipoprotein secretion and not by affecting its catabolism. Impaired lipid availability in enterocytes seems to be the primary mechanism for the PA-induced reduction of $\mathrm{CM}$ secretion. In this context, PA increase the faecal excretion of cholesterol in rats and inhibit the activity of pancreatic lipase in vitro, (Moreno et al., 2003) indicating reduced lipid absorption. Moreover, PA represses the expression of long chain acylCoA synthetases (ACSL)-5 and-3, which supply fatty acids for $\mathrm{TG}$ synthesis in enterocytes. Thus, the results of this study are agreement with the well-defined hypolipidemic and cardioprotective effect of proanthocyanidins.

The presented findings showed that, obese rats group showed significant increase in liver tissue L-MDA and markedly decreased catalase activity and GSH level when compared to control group. Similarly, Balkan et al., (2002) reported that, highcholesterol (HC) diet had an increasing effect on lipid peroxidation in plasma and tissue in rabbits. High fat diet (HFD) has a role in 
generating oxidative stress, which results from an imbalance between the production of free radicals, and the scavenger antioxidant system (Balkan et al., 2004). Obesity is also associated with oxidative stress, which may be due to extended postprandial hyperlipidemia and/or hyperglycemia. Obese humans have increased levels of oxidative stress and this is ameliorated by diet restriction and weight loss (Dandona et al., 2001). Also, obesity is associated with increased activities of the secondary product of lipid peroxidation, and weight loss has positive effects on oxidative stress and antioxidant activity (Uzun et al., 2004). Moreover, increased lipid profile could also contribute to increased oxidative stress in obesity, where increased lipid substrate in the tissues may increase the mechanical and metabolic load on such tissues, thus increasing oxygen consumption. A negative consequence of the elevated oxygen consumption is the production of reactive oxygen species (ROS) (Vaz et al., 1997). Lipid peroxidation is a marker of cellular damage initiated by ROS. In obesity, lipid peroxidation is thought to play a role in the etiology of existing health problems, such as cardiovascular disorders.Increased lipid peroxidation is considered responsible for impairment of endothelial cells, capillary permeability and vascular integrity (Keidar et al., 2004). Further increase in superoxides, $\mathrm{H}_{2} \mathrm{O}_{2}$, hydroxyl radicals and lipid peroxidation consequently cause decrease in the effectiveness of antioxidant defenses, like SOD, CAT and GPx (Hafize et al., 2007).

Treatment with Proanthocyanidins to obese rats caused a significant decrease in liver tissue L-MDA and marked increase in catalase activity and GSH level when compared to obesity non treated group. These results were nearly similar to Song et al., (2012) who suggested that, the protective effects of PA against obesity and hepatic ischemic reperfusion injury (IRI) were related with their roles in reducing the tissue oxidative stress level as GSP $20 \mathrm{mg} / \mathrm{kg} /$ day for 3 weeks decrease oxidative stress by reducing MDA content and elevating of superoxide dismutase (SOD), (CAT), glutathione peroxidase (GSH$\mathrm{PX}$ ), total nitric oxide synthase (T-NOS) and iNOS in high-fat diet induced obese mice. As reactive oxygen species (ROS) play important part in obesity and hepatic IRI, GSP have potential protective effects against obesity and hepatic IRI as showed its ideally protective effects on curbing the obesity on mice, reducing hepatic fat content and against liver IRI: particularly in high-fat diet induced obese mice. Also, Fernandez-Iglesias et al., (2013) demonstrated that, GSPE administration improves the liver GSH metabolism, and in consequence, increases the total antioxidant capacity of the cell and improve the antioxidant enzymes activity which indicated an improvement in the redox homeostasis by the polyphenol content in GSPE in a rat model of genetic obesity which might be due to the oxidative stress-reducing capacity and inhibition of the generation of superoxide anions and hydroxyl free radicals (Shrivastava et al., 2013). In view of its ability to scavenge ROS, PA can stabilize and inactivate free radicals by donating an electron to free radical -OH groups attached to the phenolic ring, which helps to terminate oxidative chain reactions.

The Presented data exhibited that, obese rats showed significant up-regulation of Leptin and NF- $\kappa \mathrm{B}$ gene expression level in liver tissue when compared to normal control group. These results were nearly similar to Tulipano et al., (2004) who showed that, leptin level was higher in adult male SpragueDawley rats fed a high-fat diet $(31 \%$ of energy) for one week. Most obese individuals 
have high concentrations of leptin but exhibit leptin resistance because of decreased leptin transport into the central nervous system or down regulation of leptin receptors (Bjorbaek et al., 1999). Leptin communicates the amount of stored energy to the brain and activates the hypothalamic center which regulates energy intake and in turn body energy expenditure (Metwally et al., 2017). The amount of stored triglycerides in the adipose tissue correlates to the expression of leptin and circulating leptin concentrations (Considine et al., 1996). There is provide evidence that, leptin was elevated in obese human (Orel et al., 2004) and animals (Scarpace and Zhang, 2008). Moreover, Masoud and Adel, (2006) reported that, serum leptin concentration was increased in relation to increased body fat content. The positive correlation between body fat and serum leptin is probably explained by the increased release of leptin from large fat cells. Thus, leptin can serve as an indicator of fat content and its level may be decreased by reduction of body weight. Additionally, Lin et al., (2000) suggested that, during high fat feeding animals are sensitive to the food lowering effect of leptin. However, despite the reduction in food intake, animals become fat as a result of the increase in food efficiency leading to an increase in leptin level followed by resistance to its action. Leptin is a cytokine like polypeptide produced by the adipocytes and it is overproduced during obesity due to the generation of ROS (Assal et al., 2007). Inflammation is a host defense mechanism to protect against pathogens, stresses and tissue damage, and is a major factor in the progression of many chronic diseases including ulcerative colitis, diabetes, atherosclerosis, obesity and arthritis (Nathan , 2002). The inflammatory response to foreign pathogens and general stressful insults involves a combination of different signaling elements such as cytokines, nitric oxide (NO) and two key transcription factors, nuclear factor-kappa B (NF- $\kappa \mathrm{B})$ and nuclear factor (erythroid- derived 2)-like2 (Nrf2) is activated in most cell types as mice-fed HFD displayed about 3.5-fold increased whole body NF- $\kappa \mathrm{B}$ activity (Wardyn et al., 2015). Additionally, De Souza et al., (2008) reported that, NF-кB is increased about twofold in the liver, hypothalamus and skin of rodents fed with HFD for 6 months compared with animals fed with a control diet. NF- $\kappa \mathrm{B}$ was similarly elevated in the liver and skin in common genetic obesity models of genetic hyperphagia (ob/ob mice and fa/fa rats) (Katiyar and Meeran, 2007).

Treatment with Proanthocyanidins to obese rats caused a significant downregulation of Leptin and NF- $\kappa \mathrm{B}$ gene expression level in liver tissue when compared to obesity non treated group. These results are nearly similar to those recorded by Boque et al., (2012) who reported that, supplementation of high-fat-sucrose diet with proanthocyandins during 8 weeks $(700 \mathrm{mg} / \mathrm{Kg}$ body weight) prevented body weight and adiposity gain promoted by this obesogenic diet, and decrease leptin level without changes in food intake. Results of leptin gene expression are in line with the decreased circulating leptin levels and reflect the reduced fat mass observed in proanthocyandins supplemented animals. The NF- $\kappa \mathrm{B}$ complex is a heterodimer of two subunits, p50 and p65, which exist in the cytoplasm in an inactive form, and it is related to the inhibitory subunit, inhibitor protein $\kappa \mathrm{B}-\alpha(\mathrm{I} \kappa \mathrm{B}-\alpha)$. inflammation and ROS stimulate NF- $\kappa \mathrm{B}$ activation by enhancing the dissociation of cytoplasmic NF$\kappa \mathrm{B}$ from I $\mathrm{B}-\alpha$, thereby allowing NF- $\kappa \mathrm{B}$ to migrate to the nucleus (Noh et al., 2006), where it binds to promoters of NF- $\mathrm{KB}$ regulated genes to initiate gene transcription (Li and Verma, 2002). Yokozawa et al., 
(2012) Reported that, a significant increase in the NF- $\mathrm{BBp} 65$ protein level and significant reduction of the I $\mathrm{KB}-\alpha$ protein level were observed in the diabetic rat. However the administration of proanthocyanidin led to a

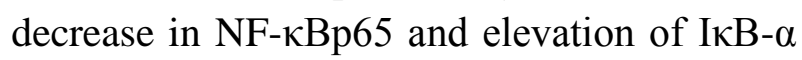
protein, indicating that proanthocyanidin suppressed the translocation of NF- $\kappa B$ to the nucleus, where it binds to the promoters of NF- $\kappa$ B-regulated genes and initiates gene transcription. Terra et al., (2007) found that, proanthocyandins treatment decreased NF- $\kappa B$ in liver, which is directly associated with the decreased hepatic expression of such inflammatory molecules as TNF- $\alpha$ and Creactive protein (CRP). Proanthocyandins also reduce Monocyte chemoattractant protein-1 (MCP-1) secretion in adipocytes partially due to the diminished TNF- $\alpha$ levels that we have detected in adipose tissue, muscle and liver, which might be a consequence of the inhibitory effects of proanthocyandins on NF$\kappa \mathrm{B}$ activation. Also, Kim et al., (2018) showed that, GSPE treatment diminishes the phosphorylation of $\mathrm{I} \kappa \mathrm{B} \alpha$ and inhibits nuclear translocation of p65 and p50 NF- $\kappa \mathrm{B}$ subunits. The results indicate that GSPE inhibits NF- $\kappa B$ activation through the suppression of $\mathrm{I} \kappa \mathrm{B} \alpha$ phosphorylation as PA is a strong antioxidant and anti-inflammatory agent.

\section{Conclusion:}

The present study demonstrated that, administration of Proanthocyanidins improve the harmful effects caused by high fat diet induced obesity. Obesity exaggerated different organs mainly liver and these occurred through changes in several parameters. high fat diet induced obesity caused significant increase in serum insulin,total cholesterol, triacylglycerols and liver tissue L- MDA, Leptin and NF- $\mathrm{NB}$. However, a significant reduce in liver tissue catalase and GSH were shown in obese rats. Proanthocyanidins treatment in obese rats relieved all aforementioned parameters near its normal range with best results after 8 weeks. So, these effects confirmed the strong antioxidant, antiinflammatory properties of Proanthocyanidins in obesity.

\section{REFERENCES}

Arola, L., Blade, C., Salvado, M.J. 2010. Hypolipidemic effects of proanthocyanidins and their underlying biochemical and molecular mechanisms. Mol. Nutr. Food Res. 54, 37-59.

Assal, H.S., Fath-Allah, M., Elsherbiny, A. 2007. Serum leptin and adiponectin in obese diabetic and non-diabetic, $\mathrm{J}$ Med Sci., 7, 865-869.

Balkan, J., Dogru-Abbasoglu, S., AykacToker, G., Uysal, M. 2004. The effect of a high cholesterol diet on lipids and oxidative stress in plasma, liver and aorta of rabbits and rats. Nutr. Res. 24: 229 -234.

Balkan, J., Kanbagl1, O., Hatipoglu, A., Kucuk, M.C., Evikbas, U. AykacToker, G., Uysal, M. 2002. Improving effect of dietary taurine supplementation on the oxidative stress and lipid levels in the plasma, liver and aorta of rabbits fed on a high-cholesterol diet. Biosci Biotechnol Biochem.66: 17551758.

Bjorbaek, C., El Haschimi, K., Frantz, J.D., Flier, J.S. 1999. The role of SOCS-3 in leptin signaling and leptin resistance. J. Biol. Chem. 274: 30059-30065.

Blade, C., Aragones, G., Arola-Arnal, A., Muguerza, B., Bravo, F.I., Salvado, M.J. 2016. Proanthocyanidins in 
health and disease. Biofactors 42: 5-12.

Boque, N., Campion, J., Iglesia, R., Garza, d. 2012. Screening of polyphenolic plant extracts for anti-obesity properties in Wistar rats. J. Sci. Food. Agric. In press.

Bray, G.A. 2004. Medical Consequences of Obesity. J. Clin. Endocrinol. Metab. 89: 2583-2589.

Chandrasekaran, C.V., Vijayalakshmi, M.A., Prakash, K., Bansal, V.S., Meenakshi, J, Amit, A. 2012 eview article: Herbal approach for obesity Management. Am. J. Plant Sci. 3, 1003-1014.

Cherniack, E.P. 2008 Potential applications for alternative medicine to treat obesity in an aging population. Altern Med Rev 13: 34-42.

Considine, R., Sinha, M.K., Heiman, M.L., Kriauciunas, A., Stephens, T.W., Nyce, M.R., Ohannesian, J.P., Marco, C.C., Mckee, L.J., Bauer, T.L., Caro, J.F. 1996. Serum immuno reactiveleptin concentrations in normal-weight and obese humans. New Engl.J.Med. 334: 292-295.

Cook, M.E., Cantor, M.J. 2006. White Paper on Cardiovascular Disease in New Jersey: Review of Current Strategies and Opportunities. Rutgers Center for State Health Policy New Brunswick, NJ, USA.

Cyrus, T., Yao, Y., Rokach, J., Tang, L. X., Pratico, D. 2003. Vitamin E reduces progression of atherosclerosis in low-density lipoprotein receptordeficient mice with established vascular lesions. Circulation. 107: 521-523.

Dandona, P., Mohanty, P., Ghanim, H., Aljada, A., Browne, R., Hamouda, W., Prabhala, A., Afzal, A., Garg, R. 2001. The suppressive effect of dietary restriction and weight loss in the obese on the generation of reactive oxygen species by leukocytes, lipid peroxidation, and protein carbonylation. J. Clin Endocrinol Metab. 86:355-362.

De Souza, C.T., Araujo, E.P., Bordin, S., Ashimine, R., Zollner, R.L., Boschero, A.C., Saad, M.J., Velloso, L.A. 2005. Consumption of a fat-rich diet activates a proinflammatory response and induces insulin resistance in the hypothalamus. Endocrinology 146:4192-4199.

Dorenkott, M., Griffin, L., Goodrich, K., Thompson-Witrick, K., Fundaro, G., Ye, L., Stevens, J., Ali, M., O'Keefe, S., Hulver, M., Neilson, A. 2014. Oligomeric Cocoa Procyanidins Possess Enhanced Bioactivity Compared to Monomeric and Polymeric Cocoa Procyanidins for Preventing the Development of Obesity, Insulin Resistance, and Impaired Glucose Tolerance during High-Fat Feeding. Journal of Agricultural and Food Chemistry, 62(10), pp.22162227.

Fernandez-Iglesias, A., Pajuelo, D., Quesada, H., Díaz, S., Bladé, C., Arola, L., Salvadó, M., Mulero, M. 2013. Grape seed proanthocyanidin extract improves the hepatic glutathione metabolism in obese 
Zucker rats. Molecular Nutrition \& Food Research, 58(4), pp.727-737.

Gil-Cardoso, K., Gines, I., Pinent, M., Ardévol, A., Arola, L., Blay, M., Terra, X. 2017. Chronic supplementation with dietary proanthocyanidins protects from diet-induced intestinal alterations in obese rats. Molecular nutrition \& food research, 61(8).

Hafize, U., Dildar, K., Remisa, G., Kagan, Z., Mustafa. 2007. Plasma Protein Carbonyl and Thiol Stress Before and After Laparoscopic Gastric Banding in Morbidly Obese Patients Obesity Surgery; 17:1367-1373.

Haslam, D.W., James, W.P. 2005 Obesity. Lancet.366:1197-1209.outcome measures: Assessment and clinical implications. Obesity.10: 14-21.

Ibars, M., Ardid-Ruiz, A., Suárez, M., Muguerza, B., Bladé, C., Aragonès, G. 2017. Proanthocyanidins potentiate hypothalamic leptin/STAT3 signalling and Pomc gene expression in rats with dietinduced obesity signalling. Int $\mathbf{J}$ Obes (Lond) 41: 129-136

Katiyar, S.K., Meeran, S.M. 2007. Obesity increases the risk of UV radiationinduced oxidative stress and activation of MAPK and NFkappaB signaling. Free Radic Biol Med 42:299-310

Keidar, S., Kaplan, M., Pavlotzky, E., Coleman, R., Hayek, T., Hamoud, S., Aviram, M. 2004. Aldosterone administration to mice stimulates macrophage NADPH oxidase and increases atherosclerosis development: A possible role for angiotensin-converting enzyme and the receptors for angiotensin II and aldosterone. Circulation. 109: 22132220.

Kim, S., Bang, J., Son, C., Baek, W., Kim, J. 2018. Grape seed proanthocyanidin extract ameliorates murine autoimmune arthritis through regulation of TLR4/MyD88/NF- $\kappa \mathrm{B}$ signaling pathway. The Korean Journal of Internal Medicine, 33(3), pp.612-621.

Li, Q., Verma, I. 2002. Erratum: NF- $\kappa \mathrm{B}$ regulation in the immune system. Nature Reviews Immunology, 2(12), pp.975-975.

Lin, S., Storlien, L.H., Huang, X. F. 2000. Leptin receptor, NPY, POMC mRNA expression in the dietinduced obese mouse brain. Brain Res. 875: 89-95.

Livak, K.J., Schmittgen, T.D. 2001. Analysis of relative gene expression data using real-time quantitative PCR and the $2-\Delta \Delta \mathrm{CT}$ Method. Methods; 25(4):402-408.

Luck, H. 1974. Estimation of catalase. In: methods in enzymatic analysis. 2nd edition, Bergmeyer, Academic Press, New York. Pp.885-890.

Manach, C., Regerat, F., Texier, O., Agullo, G., Demigne, C., Remesy, C. 1996. Bioavailability, metabolism and physiological impact of 4-oxoflavonoids. Nutrition Research, 16(3), pp.517-544.

Martinez-Micaelo, N., Gonzalez-Abuín, N., Ardevol, A., Pinent, M., Blay, M.T. 2012. Procyanidins and inflammation: molecular targets and 
health implications. Biofactors 38: 257-265.

Masoud, A.Y., Adel, A.A. 2006. Correlation between serum leptin, body mass index and obesity in Omanis. Sultan Qaboos Med. J. 6: 28-31.

Mesbah, L., Soraya, B., Narimane, S., Jean, P.F. 2004. protective effect of flavonides against the toxicity of vinblastine cyclophosphamide and paracetamol by inhibition of lipid peroxydation and increase of liver glutathione. Haematol.7 (1): 59-67.

Metwally, F., Rashad, H., Ahmed, H., Mahmoud, A., Abdol Raouf, E., Abdalla, A. 2017. Molecular mechanisms of the anti-obesity potential effect of Moringa oleifera in the experimental model. Asian Pacific Journal of Tropical Biomedicine, 7(3), pp.214-221.

Mlinar, B., Marc, J., Janez, A., Pfeifer, M. 2007. Molecular Mechanisms of Insulin Resistance and Associated Diseases. Clinica Chimica Acta, 375, 20-35.

Montagut., G., Blade, C., Blay, M., Fernández-Larrea, J., Pujadas, G., Salvado, M.J. 2010. Effects of a grapeseed procyanidin extract (GSPE) on insulin resistance. J Nutr Biochem 21: 961-967.

Moreno, D., Ilic, N., Poulev, A., Brasaemle, D., Fried, S., Raskin, I. 2003. Inhibitory effects of grape seed extract on lipases. Nutrition, 19(10), pp.876-879.

Moron, M. S., Depierre, J. W., Mannervik, B. 1979.Levels ofglutathione, glutathione reductase and glutathione S-transferase activities in rat lung and liver. Biochimica et Biophysica ACTA 582, 67-78.

Nathan, C. 2002. Points of control in inflammation. Nature. 420:846 \pm 852 .

NCEP expert panel. 1988. (NCEP) Expert Panel on Detection, Evaluation, and Treatment of High Blood Cholesterol in Adults. circulation, 148:36-69.

Noh, E.J., Ahn, K.S., Shin, E.M., Jung, S.H., Kim, Y.S. 2006. Inhibition of lipopolysaccharide-induced iNOS and COX-2 expression by dehydroevodiamine through suppression of NF-kappaB activation in RAW 264.7 macrophages. Life Sci. Jul 10;79(7):695-701.

Orel, M., Lichnovska, R., Gwozdziewiczova, S., Zlamalova, N., Klementa, I., Merkunova, A., Hrebicek, J. 2004. Gene differences in tumor necrosis factor alpha and leptin secretion from subcutaneous and visceral fat tissue. Physiol Res. 53: 501-505.

Pajuelo, D., Quesada,H., Díaz,S., FernándezIglesias, A., Arola-Arnal, A., Bladé, C., Salvadó, J., Arola L. 2012. Chronic dietary supplementation of proanthocyanidins corrects the mitochondrial dysfunction of brown adipose tissue caused by dietinduced obesity in Wistar rats. Br. J. Nutr., 107(2):170-8.

Pallares, V., Fernandez-Iglesias, A., Cedo, L., Castell-Auvi, A. 2013. Grape seed procyanidin extract reduces the endotoxic effects induced by lipopolysaccharides in rats. Free Radic. Biol. Med.

Pataki, T., Bak, I., Kovacs, P., Baqchi, D., Das, D.K., Tosaki, A. 2002. Grape 
seed proanthocyanidins improved cardiac recovery during reperfusion after ischemia in isolated rat hearts. Am J Clin Nutr. 75(5):894-899.

Pons, Z., Guerrero, L., Margalef, M., Arola, L., Arola-Arnal, A., Muguerza, B. 2014. Effect of low molecular grape seed proanthocyanidins on blood pressure and lipid homeostasis in cafeteria diet-fed rats. J Physiol Biochem 70: 629-637.

Pons, Z., Margalef, M., Bravo, F.I., ArolaArnal, A., Muguerza, B. 2017. Chronic administration of grapeseed polyphenols attenuates the development of hypertension and improves other cardiometabolic risk factors associated with the metabolic syndrome in cafeteria diet-fed rats. Br. J. Nutr., 117, 200208.

Quesada, H., del Bas, J.M., Pajuelo, D., Diaz, S., Fernandez-Larrea, J., Pinent, M. 2009. Grape seed proanthocyanidins correct dyslipidemia associated with a high-fat diet in rats and repress genes controlling lipogenesis and VLDL assembling in liver. Int $\mathbf{J}$ Obes (Lond) 33: 1007-1012.

Quesada, H., Diaz, S., Pajuelo, D., FernándezIglesias, A., Garcia-Vallvé, S., Pujadas, G., Salvadó, M., Arola, L. Blade, C. 2012. The lipid-lowering effect of dietary proanthocyanidins in rats involves both chylomicronrich and VLDL-rich fractions. British Journal of Nutrition, 108(02), pp.208-217.

Rask-Madsen, C., King, G.L. 2007. Mechanisms of disease: endothelial dysfunction in insulin resistance and diabetes. Nat. Clin. Pract. Endocrinol. Metab. 3:46-56.

Ross, R. 1999. Atherosclerosis-an inflammatory disease. $\mathrm{N}$ Engl $\mathrm{J}$ Med. 340: 15-26.

Scarpace, P. J., Zhang, Y. 2008. Leptin resistance: a prediposing factor for diet-induced obesity. Regul Integr Comp Physiol. 296: 493-500.

Shrivastava, A., Chaturvedi, U., Singh, S. V., Saxena, J. K. 2013. Lipid lowering and antioxidant effect of miglitol in triton treated hyperlipidemic and high fat diet induced obese rats. Lipids 8, 597-607.

Song, X., Xu, H., Feng, Y., Li, X., Lin, M., Cao, L. 2012. Protective Effect of Grape Seed Proanthocyanidins against Liver Ischemic Reperfusion Injury: Particularly in Diet-Induced Obese Mice. International Journal of Biological Sciences, 8(10), pp.1345-1362.

Stein, E.A. 1987. Lipids, lipoproteins, and apolipoproteins.In :NW Tietz,ed Fundementals of clinical chemistry. 3 rd ed.Philadelphia : WB Saunders;448.

Surapaneni, K.M., JAINU, M. 2014. Comparative effect of pioglitazone, quercetin and hydroxy citric acid on the status of lipid peroxidation and antioxidants in experimental nonalcoholic steatohepatitis. Journal of physiology and pharmacology, 65 (1), 67-74.

Taboada, M.C., Rodriguez, B., Millan, R., Miguez, I. 2006. Role of dietary 1arginine supplementation on parameters and intestinal enzyme 
activity in rats. Biomed. And pharmacother. 60: 10-19.

Terra, X., Pallares, V., Ardevol, A., Bladé, C., Fernández-Larrea, J., Pujadas, G., Salvado, J., Arola, L., Blay, M. 2011. effect of grape-seed procyanidins on local and systemic inflammation in diet-induced obesity rats. J. Nutr. Biochem., 22, 380-387.

Terra, X., Valls, J., Vitrac, X., Merrillon, J.M., Arola, L., Ardevol, A. 2007. Grapeseed procyanidins act as antiinflammatory agents in endotoxin-stimulated RAW264.7 macrophages by inhibiting NFkB signaling pathway. J Agric Food Chem55 (11):4357-65.

Tulipano, G., Vergoni, A.V., Soldi, D. Muller, E.E., Cocchi, D. 2004. Characterization of the resistance to the anorectic and endocrine effects of leptin in obesity-prone and obesity-resistant rats fed a high-fat diet. J. Endocrinol. 183:289-298.

Uzun, H., Zengin, K., Taskin, M., Aydin, S., Simsek, G., Darryerli, N. 2004. Changes in leptin, plasminogen activator factor and oxidative stress in morbidly obese patients following open and laparoscopic Swedish adjustable gastric banding. Obes. Surg. 14: 659-665.

Vaz, M., Jennings, G., Turner, A., Cox, H. Lambert, G., Esler, M. 1997. Regional sympathetic nervous activity and oxygen consumption in obese normotensive human subjects. Circulation. 96: 3423- 3429.

Veilleux, A., Caron-Jobin, M., Noël, S., Laberge, P.Y., Tchernof, A. 2011.
Visceral adipocyte hypertrophy is associated with dyslipidemia independent of body composition and fat distribution in women. Diabetes, 60, 1504-1511.

Wang, G., Siow, Y.L., O, K. 2000. Homocysteine stimulates nuclear factor kappaB activity and monocyte chemoattractant protein-1 expression invascular smoothmuscle cells: a possible role for protein kinase C. Biochem J, 352: 817-826.

Wardyn, J.D., Ponsford, A.H., Sanderson, C.M. 2015. Dissecting molecular cross-talk between Nrf2 and NF-kB response pathways. Biochem Soc Trans. 43:621 626 .

Westerbacka, J., Yki-Jarvinen, H., Turpeinen, A., Rissanen, A., Vehkavaara, S., Syrjala, M., Lassila, R. 2002. Inhibition of platelet-collagen interaction: an in vivo action of insulin abolished by insulin resistance in obesity. Arterioscler Thromb Vasc Biol. 22:167-172.

Wilson, M.A., Miles, L.S.M. 1977. Radioimmunoassay of insulin. In hand book of Radioimmunoassay, G.E. Abraham (ed.), M. Dekker Inc., New York, 275-279.

Woods, S.C., D'Alessio, D.A., Tso, P., Rushing, P.A., Clegg, D.J., Benoit, S.C., Gotoh,K. Liu, M., Seeley, R.J. 2004. Consumption of a high-fat diet alters the homeostatic regulation of energy balance. Physiol. Behav. 83: 573-578.

Yokozawa, T., Cho, E.J., Park, C.H., Kim, J.H. 2012. Protective Effect of Proanthocyanidin against Diabetic 
Antiobesity activity and hypolipidemic effect of Proanthocyanidins in rats fed a high fat diet

Oxidative Stress. Evid Based

Complement

Alternat

Med.2012:623879.

You, J.S., Lee, Y.J., Kim, K.S., Kim, S.H., Chang, K.J. 2014. Anti-obesity and hypolipidaemic effects of Nelumbo nucifera seed ethanol extract in human pre-adipocytes and rats fed a high-fat diet. J Sci Food Agric 94: 568-575. 